\title{
Cloning and characterization of the yak gene coding for calpastatin and in silico analysis of its putative product
}

\author{
Liping Zhang ${ }^{1 \star} \bowtie$, Binyun Ma ${ }^{2 \star}$, Jianping Wu${ }^{1}$, Chunhong Fei ${ }^{1}$, Lian Yang ${ }^{1}$ \\ and Hongling Wan ${ }^{1}$ \\ 'College of Animal Science and Technology, Gansu Agricultural University, Lanzhou, China; 2 School of Life Sciences, Lanzhou University, \\ Lanzhou, China
}

The calcium-activated neutral proteases, $\mu$ - and $\mathrm{m}$-calpain, along with their inhibitor, calpastatin, have been demonstrated to mediate a variety of $\mathrm{Ca}^{2+}$-dependent processes including signal transduction, cell proliferation, cell cycle progression, differentiation, apoptosis, membrane fusion, platelet activation and skeletal muscle protein degradation. The cDNA coding for yak calpastatin was amplified and cloned by RT-PCR to investigate and characterize the nucleotide/amino-acid sequence and to predict structure and function of the calpastatin. The present study suggests that the yak calpastatin gene encodes a protein of 786 amino acids that shares $99 \%$ sequence identity with the amino-acid sequence of cattle calpastatin, and that the yak protein is composed of an $\mathrm{N}$-terminal region (domains $\mathrm{L}$ and $\mathrm{XL}$ ) and four repetitive homologous C-terminal domains (d1-d4), in which several prosite motifs are present including short peptide L54-64 (EVKPKEHTEPK in domain L) and GXXE/ DXTIPPXYR (in subdomain $B$ ), where $X$ is a variable amino acid. Our results suggest the existence of other functional sites including potential phosphorylation sites for protein kinase C, CAMP- and CGMP-dependent protein kinase, casein kinase II, as well as $\mathrm{N}$-myristoylation and amidation sites that play an important role in molecular regulation of the calpain/calpastatin system. The regulation of the calpain/calpastatin system is determined by the interaction between dIV and dVI in calpains and subdomains $A, B$, and $C$ in calpastatin.

Keywords: calpastatin, yak, domain, motif, functional site, calpaincalpastatin system

Received: 31 July, 2009; revised: 9 March, 2009; accepted: 16 March, 2010; available on-line: 19 March, 2010

\section{INTRODUCTION}

Calpains (CAPN, EC 3.4.22.17) belong to a family of calcium-dependent cytoplasmic cysteine proteinases that require $\mathrm{Ca}^{2+}$ for activity. Two types of CANP, $\mu$-calpain (or CAPN I) and m-calpain (or CAPN II), which require approximately 50 and $300 \mu \mathrm{M} \mathrm{Ca}{ }^{2+}$ for half-maximal activity in vivo, respectively, exist widely in mammalian tissues (Hirose et al., 1999; Shiraha et al., 2002; Goll et al., 2003). Calpastatin (CAST) is a specific endogenous inhibitor of $\mu$-calpain and $\mathrm{m}$-calpain, which regulates calpain activity in vivo (Carragher et al., 2002; Goll et al., 2003). Whereas only one calpastatin gene has been identified, several forms of the gene product, resulting from differential mRNA splicing and posttranslational modifications such as phosphorylation and proteolysis, have been detected (Croall \& Demartino, 1991; Glading et al., 2002; Weber et al., 2004). Calpastatin is ubiquitously expressed and is translated as two main calpastatin isoforms, including a $110-\mathrm{kDa}$ muscle tissue type and a 70 $\mathrm{kDa}$ erythrocyte type (Tullio et al., 2000; Takano et al., 2000). Typical calpastatin molecules have five structural domains: four repetitive domains (d1 to d4) and a unique $\mathrm{N}$-terminal domain (L-domain). Calpain inhibitory activity has been detected in each repetitive domain, of which domain 1 possesses the strongest activity (Maki et al., 1987; Emori et al., 1988; Kawasaki et al., 1989). The repetitive domains contain about 140 amino-acid residues each and show 20-30\% sequence identity to each other, while the function of the N-terminal domain is not clear.

In the present study, we cloned the calpastatin gene from yak longissimus muscle, and investigated the structural and functional motifs of the yak calpastatin by bioinformatic methods.

\section{MATERIALS AND METHODS}

Animal tissue collection and total RNA isolation. Preharvest animal care and use was under control of local farmers in Tianzhu, Gansu production area, and was consistent with Gansu Agricultural University animal care and use requirements. Animals were harvested at a commercial facility that must comply with state regulations governing processing of meat animals. To clone the CAST genes, yak longissimus muscle tissues were collected from Tianzhu white yak (Bos grunniens) from Tianzhu, Gansu (China), within $10 \mathrm{~min}$ after slaughter. The samples were flash-frozen by immersion in liquid nitrogen, and stored at $-70^{\circ} \mathrm{C}$ until thawed for RNA extraction.

Total RNA was extracted with Trizol reagent (Gibco BRL, Gaithersburg, MD, USA). Yak longissimus muscle tissue samples were homogenized in $1 \mathrm{ml}$ of Trizol reagent per 50 to $100 \mathrm{mg}$ of tissue using a glass homogenizer. Homogenized samples were incubated for $5 \mathrm{~min}$ at $15^{\circ} \mathrm{C}$ to $30^{\circ} \mathrm{C}$ to permit the complete dissociation of nucleoprotein complexes. Chloroform $(0.2 \mathrm{ml} / \mathrm{ml}$ of Trizol) was added, and samples were shaken and incubated at $15^{\circ} \mathrm{C}$ to $30^{\circ} \mathrm{C}$ for an additional 2 to $3 \mathrm{~min}$. Samples were

\footnotetext{
Liping Zhang: e-mail: zhangliping@gsau.edu.cn;

\Binyun Ma: e-mail: mabinyun@hotmail.com

* Both authors contributed equally to this work

Abbreviations: CAPN, calpain; CAST, calpastatin; ORF, open reading frame; AMV, avian myeloblastosis virus; 3' UTR, 3' untranslated region; 5' UTR, 5' untranslated region.
} 
Table 1. Primers for RT-PCR of CAST gene of yak

\begin{tabular}{lcc}
\hline Primers sequences $\left(5^{\prime}\right.$ to $\left.3^{\prime}\right)$ & $\begin{array}{l}\text { Size of interesting } \\
\text { fragments }(\mathrm{bp})\end{array}$ & $\begin{array}{l}\text { Temperature } \\
\left({ }^{\circ} \mathrm{C}\right)\end{array}$ \\
\hline $\mathrm{P}_{\text {CAST }}$-F1:TGCGTCTCTCGGAACACAT & 1342 & 57 \\
$\mathrm{P}_{\text {CAST }}$-R1:CTGATTCACTCAGGGGTTG & & 60.5 \\
$\mathrm{P}_{\text {CAST }}$-F2:ACCGGCCACAGATAAAGATG & 1176 & 6 \\
$\mathrm{P}_{\text {CAST }}$-R2:AGTCACCATCTACCCGCTGA & & \\
\hline
\end{tabular}

then centrifuged at $12000 \times g$ for $15 \mathrm{~min}$ at $2{ }^{\circ} \mathrm{C}$ to $8^{\circ} \mathrm{C}$. After centrifugation, the dissolved RNA was pipetted to a fresh tube, and the RNA was precipitated with isopropyl alcohol. Samples were then incubated at $15^{\circ} \mathrm{C}$ to $30^{\circ} \mathrm{C}$ for $10 \mathrm{~min}$ and centrifuged at $12000 \times \mathrm{g}$ for $10 \mathrm{~min}$ at $2{ }^{\circ} \mathrm{C}$ to $8^{\circ} \mathrm{C}$. The supernatant was removed, and the RNA precipitate was washed with $75 \%$ ethanol. The RNA and ethanol were vortexed and centrifuged at $7500 \times \mathrm{g}$ for 5 min at $2{ }^{\circ} \mathrm{C}$ to $8^{\circ} \mathrm{C}$. The RNA was then redissolved in $100 \%$ formamide (deionized) and stored at $-80^{\circ} \mathrm{C}$.

PCR primers and RT-PCR. The oligonucleotide primers for reverse-transcription PCR (RT-PCR) were designed based on the mRNA sequences of CAST (Genbank Accession No AF159246) of the cattle (Bos taurus) published at the National Center for Biotechnology Information (http://www.ncbi.nlm.nih.gov/) (Table 1).

The RT-PCR was carried out using an RNA PCR kit (AMV), Ver. 3.1 (TaKaRa, Shiga, Japan), for which avian myeloblastosis virus reverse transcription was used for the first-strand DNA synthesis, and Taq DNA polymerase was used for PCR in a single optimized RT-PCR buffer. First-strand cDNA synthesis was accomplished by RT-PCR at $30^{\circ} \mathrm{C}$ for $10 \mathrm{~min}, 50^{\circ} \mathrm{C}$ for $30 \mathrm{~min}, 99^{\circ} \mathrm{C}$ for $5 \mathrm{~min}$, and $5^{\circ} \mathrm{C}$ for $5 \mathrm{~min}$. The initial denaturation reaction was performed for $2 \mathrm{~min}$ at $94^{\circ} \mathrm{C}$ for 1 cycle, and the amplification was carried out for 35 cycles, each comprising $30 \mathrm{~s}$ at $94^{\circ} \mathrm{C}, 1.5 \mathrm{~min}$ at the temperatures specified in Table 1 , and then $1.5 \mathrm{~min}$ at $72^{\circ} \mathrm{C}$, followed by the last elongation reaction at $72^{\circ} \mathrm{C}$ for $10 \mathrm{~min}$. Products were separated by electrophoresis on a $1.0 \%$ agarose gel. Fragments with the expected size were cut from the gel and purified using the PCR Preps DNA Purification System (Promega, Madison, WI, USA).

Cloning and sequencing of cDNA of the CAST genes. A plasmid library was constructed with T4 polymerase by ligating the amplified DNA fragments into the SphI and SalI sites of the cloning plasmid pGEM $^{\circledR}$-T Vector (Promega, Shanghai, China), following the manufacturer's procedures. Isolation of library DNA, transfection of competent Escherichia coli DH5 $\alpha$, and extraction of DNA from transfected cells were performed according to published methods (Sambrook \& Russell, 2001). Recombinant plasmids containing relevant yak DNA fragments were sequenced on an ABI Prism 3100 genetic analyzer (Applied Biosystems, Foster City, CA, USA).

Sequence analysis and molecular characterization of CAST. The nucleotide and AA sequences of yak CAST were subjected to BLAST searching at the National Center for Biotechnology Information. Multiple alignment and comparisons of the nucleotide and amino acid sequences were then performed using BioEdit (Hall, 1999; Version 7.0.5.3) and DNAMAN (Version 5.2.2; Lynnon Biosoft). Protein signal peptides were analyzed using SignalP 3.0 software (Bendtsen et al., 2004; http://www.cbs.dtu.dk/services/SignalP-3.0/). Secondary structures of CAST were predicted by DNAStar Protean (Chou \& Fasman, 1978; Chou, 1990; Version
5.01), and the prosite motifs and functional regulating sites of CAST were predicted by PROSITE motif search of the ExPASy Server (http://www.expasy.org/ prosite/).

\section{RESULTS AND DISCUSSION}

\section{Cloning and molecular characterization of calpastatin}

To study the molecular identity of calpastatin from the yak, gene-specific primers were used to amplify the entire cDNA encoding the CAST from yak longissimus muscle by RT-PCR as described in more detail in Materials and Methods (Table 1). The interesting fragments CAST-1 (about $1340 \mathrm{bp}$ ) and CAST-2 (about $1170 \mathrm{bp}$ ) were obtained by $\mathrm{P}_{\mathrm{CAST}^{-}}-\mathrm{F} 1 / \mathrm{P}_{\mathrm{CAST}^{-}}-\mathrm{R} 1$ and $\mathrm{P}_{\mathrm{CAST}^{-}}-\mathrm{F} 2 / \mathrm{P}_{\mathrm{CAST}^{-}}$ R2, respectively (Fig. 1).

Assembly of the CAST gene fragments generated a full-length CAST cDNA (2445 bp, Genbank Accession No EU009141). In the CAST cDNA complete open reading frame (2361 bp) was present encoding a protein of 786 amino acids $99 \%$ identical to that of the cattle CAST gene (Genbank Accession No NM_174003) (Fig. 2), and sharing 99\% sequence identity with the amino-acid sequence of cattle calpastatin (Fig. 3).

\section{Functional domains, motifs and sites of CAST}

Calpastatin, an unstructured endogenous inhibitor of calpains that lack a well-defined 3D structure (Mucsi et al., 2003), has been demonstrated previously by NMR and circular dichroism spectroscopy studies to be an intrinsically disordered molecule with local preformed transient structural elements which are important for calpain recognition (Uemori et al., 1990; Kiss et al., 2008a; 2008b; Toke et al., 2009). The primary structure of calpastatin is composed of an $\mathrm{N}$ terminal region (domains $\mathrm{L}$ and $\mathrm{XL}$ ) and four repetitive homologous C-terminal domains (d1-d4) (Fig. 3). The function of the L-domain (N-terminal domain) is not clear, whereas the other four homologous domains are all capable of inhibiting a calpain molecule. In the calpastatin of yak, there are several prosite motifs and many functional sites, which may play important roles in a variety of $\mathrm{Ca}^{2+}$-dependent processes

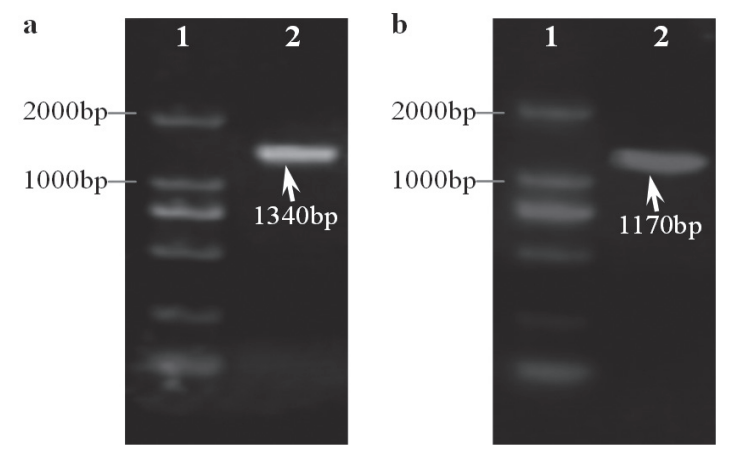

Figure 1. Amplification of CAST gene from yak longissimus muscle total RNA.

(a) PCR product with primers $P_{\text {CAST }}-\mathrm{F} 1$ and $P_{\text {CAST }}-\mathrm{R} 1$, lane 1 shows DNA Marker DL 2000 (TaKaRa, Shiga, Japan), lane 2 shows amplified fragment of $1340 \mathrm{bp}$ (CAST-1); (b) PCR product with primers $\mathrm{P}_{\text {CAST }}-\mathrm{F} 2$ and $\mathrm{P}_{\text {CAST }}-\mathrm{R} 2$, lane 1 shows DNA Marker DL 2000, lane 2 shows amplified fragment of $1170 \mathrm{bp}$ (CAST-2). 


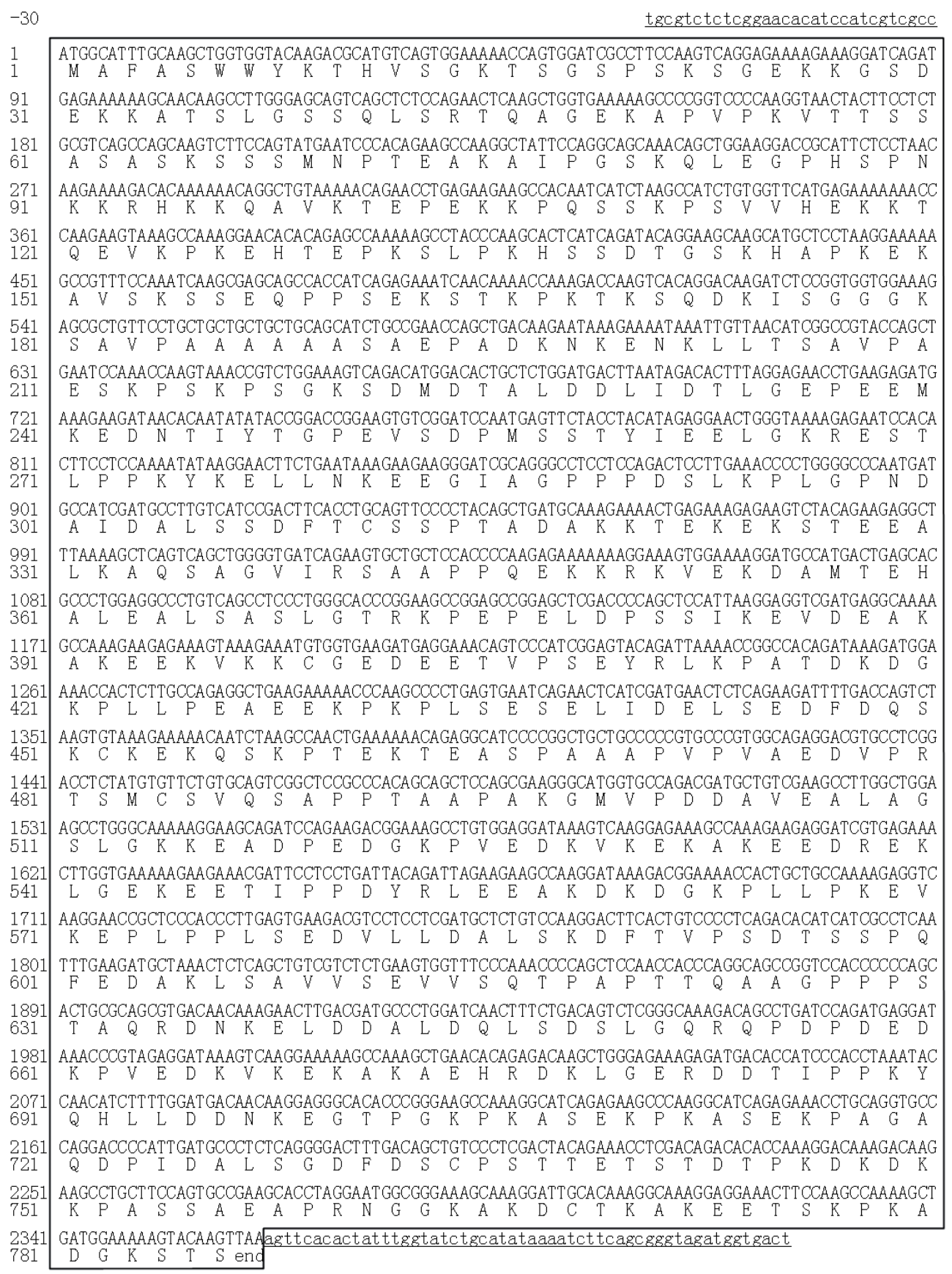

Figure 2. Full-length nucleotide sequence of CAST CDNA from yak (2445 bp) and deduced amino-acid sequence (786 aa). Positions of nucleotides and amino acids are indicated on the left, and sequences are numbered relative to the translation initiation site. The open reading frame (ORF) and encoded protein are boxed. The 3'-untranslated region (3'-UTR) and 5'-untranslated region (5'-UTR) are underlined. There is no signal peptide or membrane-anchoring domain. Potential prosite motifs and functional sites are shown in Fig. 3.

such as signal transduction, cell proliferation, cell cycle progression, differentiation, apoptosis, membrane fusion, platelet activation and skeletal muscle protein degradation (Fig. 3 and Table 2). Calpastatin protein signal peptides were analyzed using SignalP 3.0 software. Results from the protein signal peptide analysis suggest that calpastatin is a nonsecretory cytoplasmic protein. Using the Protean program of DNAStar, potential secondary structures of CAST were predicted, and the results indicated that there are $33 \alpha$-helices and eight $\beta$-sheets in the sequence of CAST (Fig. 3).

\section{Molecular basis for interaction of calpain-calpastatin system}

Based on a previous research report, we predict that the N-terminal region domain $\mathrm{L}$ of the yak calpastatin that contains a short peptide L54-64 (EVKPKEHTEPK) may be responsible for $\mathrm{Ca}^{2+}$ channel repriming function (Hao et al., 2000; Minobe et al., 2006) (Fig. 3). The homologous inhibitory domains contain three short conserved segments (subdomains A, B, and C) of about 20 amino acids each that are primarily responsible for 


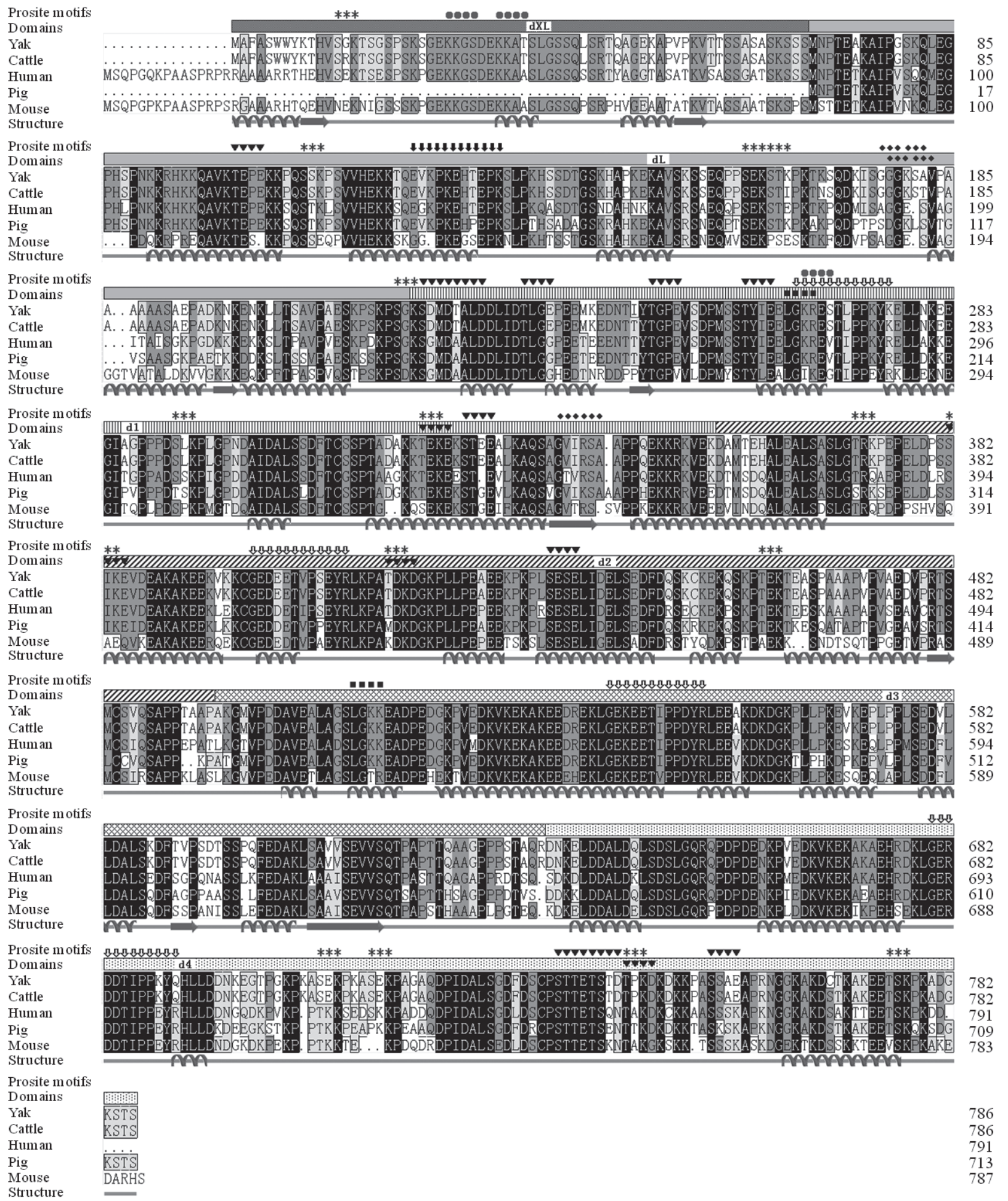

Figure 3. Multiple alignment and analysis of amino-acid sequences of mammalian calpastatins.

Secondary structural elements of the core region of yak calpastatin were predicted by DNAStar Protean, and amino-acid sequence alignment of calpastatin of the yak, cattle, human, pig, and mouse was performed by DNAMAN software (prediction identity $=81.69 \%$ ). Domains of yak calpastatin are depicted by different symbols: dXL (1 to 68), dL (69 to 219), d1 (220 to 354), d2 (355 to 495$)$, d3 (496 to 634), d4 (635 to 786). Broad arrows and wavy lines under the sequences denote potential $\beta$-sheets and a-helices, respectively. Possible prosite motifs and phosphorylation sites were obtained with PROSITE motif search of the ExPASy Server (Table 2): protein kinase C phosphorylation sites are marked by stars, CAMP- and CGMP-dependent protein kinase phosphorylation sites are marked by closed circles, casein kinase II phosphorylation sites are marked by triangles, N-myristoylation sites are marked by diamonds, amidation sites are marked by squares. The L54-64 short peptide in domain L is indicated by closed arrows, and the highly conserved repetitive 12-aa peptides in each of subdomains B are indicated by open arrows above the sequences. Letters in blue-black blocks indicate $100 \%$ homology between these sequences, and those in gray blocks indicate $\geq 60 \%$ homology. 
Table 2. Analysis of prosite motifs of yak calpastatin with ExPASy Server ${ }^{1}$

\begin{tabular}{|c|c|}
\hline Prosite motifs and sites ${ }^{2}$ & Sequences and residues \\
\hline L54-64 short peptide & E122VKPKEHTEPK \\
\hline 12-AA short peptide & G265KRESTLPPKYK, G400EDEETVPSEYR, G542EKEETIPPDYR, G680ERDDTIPPKYQ \\
\hline LYS_RICH & $\mathrm{K}^{91}$ krhkkqavktepekkpqsskpsvvhekktqevkpkehtepks/pkhssdtgskhapkekavsksseqppsekstkpktksqdK \\
\hline PKC_PHOSPHO_SITE & $\begin{array}{l}\mathrm{S}^{13} \mathrm{gK}, \mathrm{S}^{109} \mathrm{sK}, \mathrm{S}^{161} \mathrm{eK}, \mathrm{S}^{164} \mathrm{tK}, \mathrm{S}^{218} \mathrm{gK}, \mathrm{S}^{292} \mathrm{IK}, \mathrm{T}^{321} \mathrm{eK}, \mathrm{T}^{371} \mathrm{rK}, \mathrm{S}^{382} \mathrm{iK}, \mathrm{T}^{416} \mathrm{dK}, \mathrm{T}^{460} \mathrm{eK}, \mathrm{S}^{708} \mathrm{eK}, \mathrm{S}^{714} \mathrm{eK}, \mathrm{T}^{744} \mathrm{pK} \\
\mathrm{T}^{775} \mathrm{SK}\end{array}$ \\
\hline CAMP_PHOSPHO_SITE & $\mathrm{K}^{26} \mathrm{KgS}, \mathrm{K}^{32} \mathrm{KaT}, \mathrm{K}^{266} \mathrm{ReS}$ \\
\hline CK2_PHOSPHO_SITE & $\begin{array}{l}\mathrm{T}^{101} \mathrm{epE}, \mathrm{S}^{221} \mathrm{dmD}, \mathrm{T}^{225} \mathrm{alD}, \mathrm{T}^{233} \mathrm{gE}, \mathrm{T}^{248} \mathrm{gpE}, \mathrm{T}^{259} \mathrm{yiE}, \mathrm{T}^{321} \mathrm{ekE}, \mathrm{S}^{326} \mathrm{teE}, \mathrm{S}^{382} \mathrm{ikE}, \mathrm{T}^{416} \mathrm{dkD}, \mathrm{S}^{435} \mathrm{esE}, \mathrm{S}^{736} \mathrm{ttE}, \\
\mathrm{T}^{740} \mathrm{stD}, \mathrm{T}^{744} \mathrm{pkD}, \mathrm{S}^{754} \mathrm{saE}\end{array}$ \\
\hline MYRISTYL & G177GgkSA, G178GksAV, G337VirSA \\
\hline AMIDATION & |264GKR, |512GKK \\
\hline
\end{tabular}

'http://www.expasy.org/prosite/. ${ }^{2}$ LYS_RICH, lysine-rich region; PKC_PHOSPHO_SITE, protein kinase C phosphorylation site; CAMP_PHOSPHO_SITE, CAMP- and CGMP-dependent protein kinase phosphorylation site; CK2_PHOSPHO_SITE, casein kinase II phosphorylation site; MYRISTYL, N-myristoylation site; AMIDATION, amidation site.

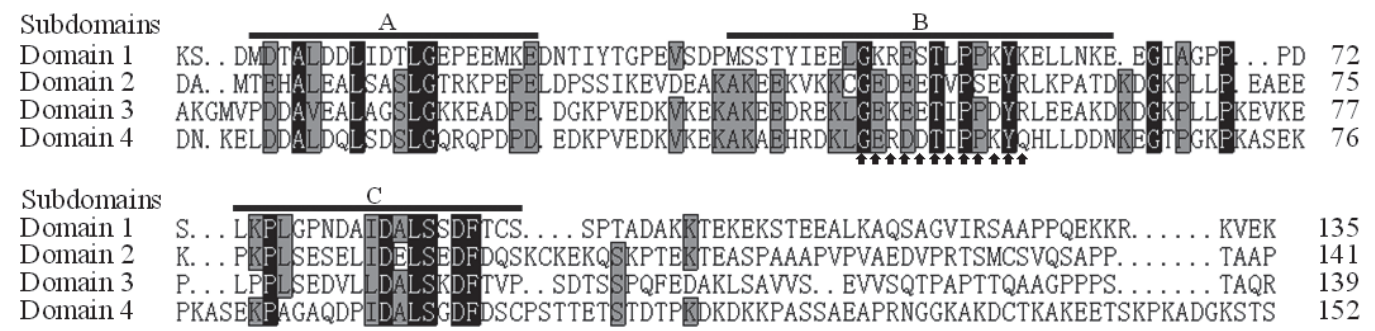

Figure 4. Alignment and analysis of yak calpastatin inhibitory domains and their subdomains A, B, and C.

The four domains of yak calpastatin inhibitory to calpain are shown aligned, which subdomains A (20 aa), B (27 aa), and C (20 aa) indicated by broad line above their sequences. Identity or strong similarity of residues extending to four (black) or three (gray) domains are marked by shading (Tompa et al., 2002). Analysis by DNAMAN indicated that the identity of subdomains A, B, and C in domains 1, 2, 3, and 4 are $61.25 \%, 62.96 \%$, and $59.52 \%$, respectively. The highly conserved repetitive 12 -aa peptides in each of subdomains B are indicated by arrows (Fig. 5).
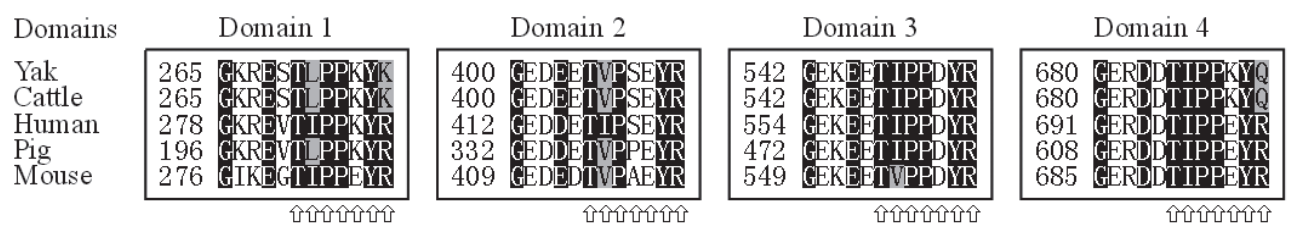

Figure 5. Alignment of the highly conserved repetitive 12-aa peptides of calpastatin domains 1, 2, 3, and 4 from yak, cattle, human, pig, and mouse.

Each of these repeating domains has inhibitory activity with functional sequence TIPPXYR indicated by open arrows. Residues of each peptide are numbered on the left.

calpain inhibition (Fig. 4). Subdomain B, a 27-residue peptide, is responsible for inhibition by binding to the active site of the enzyme, whereas subdomains $A$ and C only potentiate this inhibitory effect by anchoring the inhibitor to the calmodulin-like domains of the large and small subunits of CAPN, respectively, in a strictly $\mathrm{Ca}^{2+}$-dependent manner (Tompa et al., 2002; Mucsi et al., 2003; Melloni et al., 2006) (Fig. 4). Hence the yak calpastatin has potentially dual function, namely inhibition of calpain (domains 1-4) and the regulation of the $\mathrm{Ca}^{2+}$ channel (domain L) (Minobe et al., 2006). Subdomain $\mathrm{B}$ areas of the $\mathrm{d} 1, \mathrm{~d} 2, \mathrm{~d} 3$ and $\mathrm{d} 4$ domain contain a sequence Gly-X-X-Glu/Asp-X-Thr-Ile-Pro-Pro-X-Tyr-Arg (GXXE/DXTIPPXYR, where $\mathrm{X}$ is a variable amino acid) that appears to be important for protease inhibition (Croall \& Demartino, 1991) (Fig. 5).

The calpains and their specific competitive inhibitor calpastatin form a calpain-calpastatin system (Goll et al., 2003). The activity of calpains is tightly controlled by the endogenous inhibitor calpastatin in the presence of calcium (Wendt et al., 2004; Hanna et al., 2007), but the mechanism of inhibition by calpastatin and the basis for its absolute specificity, to date, have remained speculative (Betts et al., 2003; Todd et al., 2003; Pfizer et al., 2008). $\mu$-Calpain (or CAPN I) and m-calpain (or CAPN II) are $100-\mathrm{kDa}$ heterodimers with homologous large subunits comprising four domains (DI-DIV) and a common small subunit with two domains (DV, DVI). Calpastatin binds to the calpains at three sites on the calpain molecule: subdomain A of calpastatin to domain IV in calpain, subdomain $\mathrm{C}$ of calpastatin to domain VI in calpain, and subdomain B of calpastatin to an area near the active site (domains IIa or IIb or both) of calpain (Fig. 6). However, it was not clear how subdomain B of the unstructured protein inhibits calpains without being cleaved itself and how calcium induces changes facilitated the binding of calpastatin to calpain (Hanna 


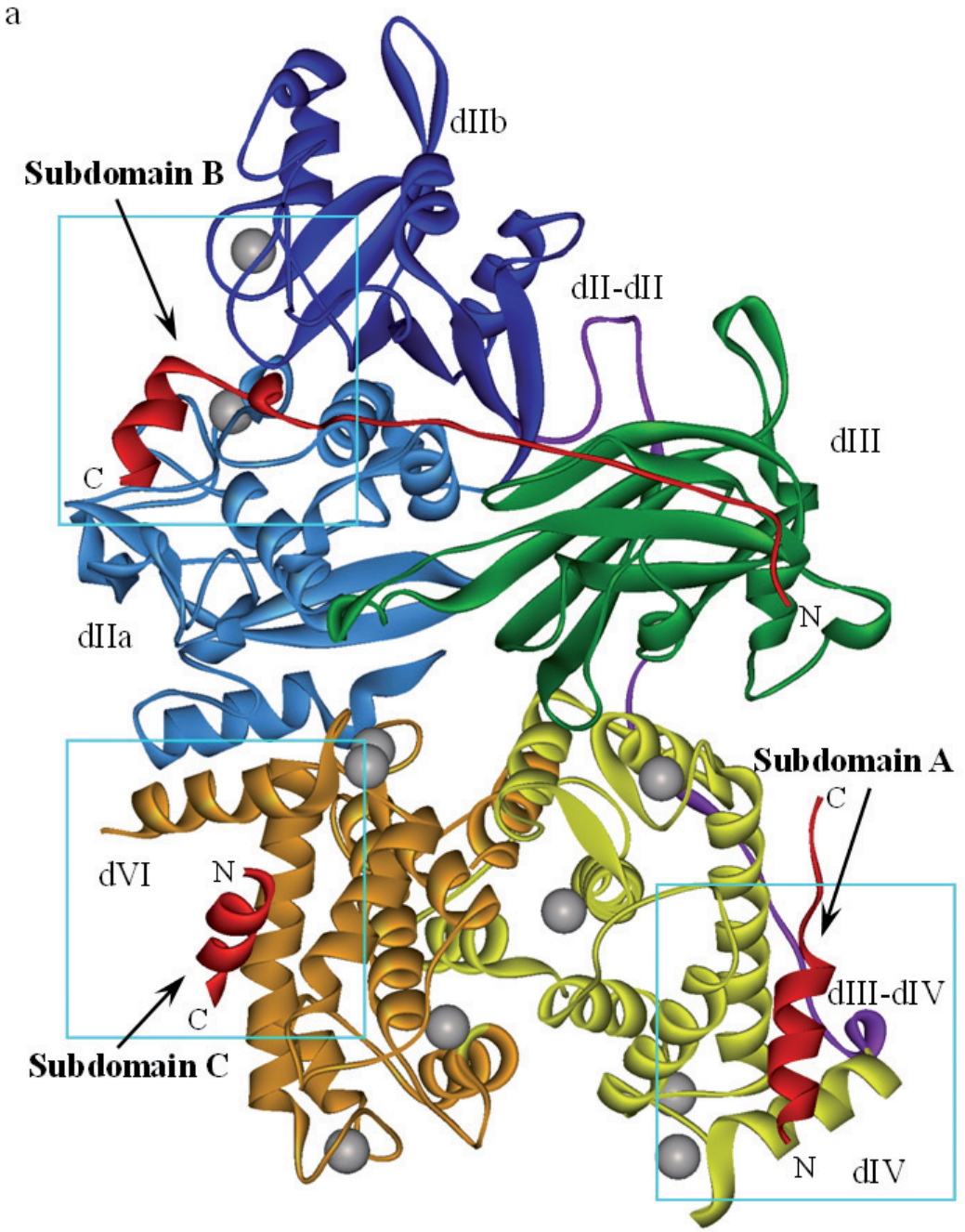

$\mathrm{b}$

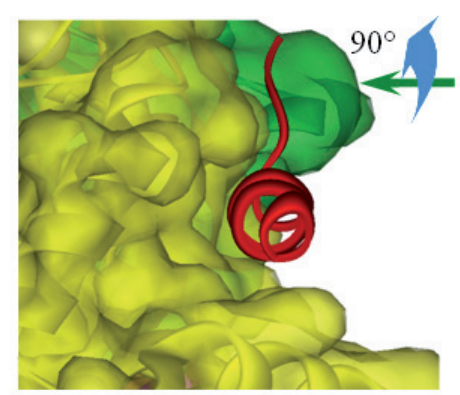

$\mathrm{c}$

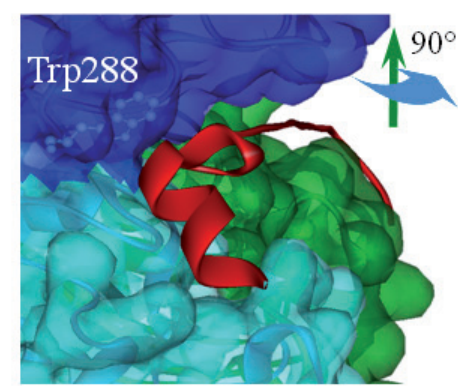

d

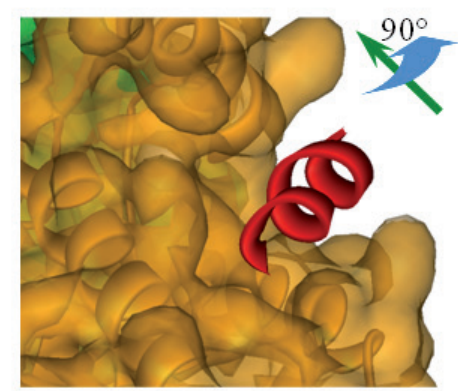

Figure 6. Structural diagram of calpastatin domain 4 (CAST4) bound to m-calpain (CAPN II).

The diagram is designed as indicated by Hanna and coworkers in their structure of m-calpain in complex with domain 4 of calpastatin (Hanna et al., 2008). (a) Schematic representation of the domain structure of the large and small subunits of $\mathrm{m}$-calpain in complex with domain 4 of calpastatin. CAST4 is unstructured in the absence of calpain, and forms three a-helices (red) when in complex with the enzyme. The helices in subdomains $\mathrm{A}$ and $\mathrm{C}$ are in contact with dIV (yellow) and dVI (orange), and the helix in subdomain B is in contact with the protease core dlla (light blue) and dllb (blue), and they are shown in solid ribbon representation. The ten $\mathrm{Ca}^{2+}$ ions in dlla, dllb, $\mathrm{dIV}$, and dVI are shown as spheres (gray). Boxes represent approximate area where subdomains A, B, and C of CAST4 bind to domains of m-calpain. (b-d) Representation of binding area of subdomains A, B, C of CAST4 with the domains of calpain, obtained from Fig. 6a by a $90^{\circ}$ rotation around an axis shown in Fig. $6 \mathrm{~b}, 6 \mathrm{c}$, and $6 \mathrm{~d}$ and shown in solid ribbon with solid surface. The helices of subdomains $\mathrm{A}, \mathrm{B}$, and $\mathrm{C}$ and $\mathrm{N}$-terminal side of subdomain $\mathrm{B}$ are buried in hydrophobic groove patch in calpain. The important residue Trp288 in the calcium-dependent activation of the protease core is shown in Fig. 6c (Todd et al., 2003).

et al., 2008; Moldoveanu et al., 2008). When bound to calpain, each subdomain $\mathrm{A}$ and subdomain $\mathrm{C}$ forms an amphipathic $\alpha$-helix that binds to an exposed hydrophobic groove patch on DIV (on the large subunit) and DVI (on the small subunit), respectively (Todd et al., 2003; Hanna et al., 2008; Moldoveanu et al., 2008). Subdomain B of calpastatin inhibits calpain by binding to the activated enzyme on the side of the active site cleft that requires interaction between calpain DIV and DVI and calpastatin subdomains $\mathrm{A}$ and $\mathrm{C}$, respectively (Fig. 6b-d). The N-terminal side of subdomain B forms hydrophobic and electrostatic interactions with a shallow groove in DIII that becomes aligned with the catalytic cleft (Fig. 6c).

Each of the domains 1, 2, 3, and 4 of calpastatin can inhibit the proteolytic activity of either $\mu$ - or $\mathrm{m}$-calpain, whereas the $\mathrm{L}$ domain of calpastatin alone has no in- hibitory activity. Theoretically, one calpastatin molecule can inhibit four calpains (Emori et al., 1988; Maki et al., 1988). The ability of the individual domains to inhibit the calpains is as follows: $\mathrm{d} 1>\mathrm{d} 4>\mathrm{d} 3>\mathrm{d} 2$, from the most to the least effective (Emori et al., 1988; Kawasaki et al., 1989). In fact, the conserved 12-amino-acid sequence (GXXE/DXTIPPXYR) in the C-terminal part of subdomains $\mathrm{B}$ areas is essential for the inhibitory activity (Figs. 5 and 6). It is reported that the maximum effective inhibition of the calpains by calpastatin requires all calpastatin subdomains, A, B, and $\mathrm{C}$ to bind simultaneously to calpain (Goll et al., 2003). Previous research (Hanna et al., 2008) indicated that 1) a shift caused by $\mathrm{Ca}^{2+}$ in the EF hands exposes hydrophobic areas and provides enough room for the binding of subdomains $\mathrm{A}$ and $\mathrm{C}$ to domains of the calpain; 2) a large structure change, caused by calcium binding to the protease core 
to align the active site, $\operatorname{Trp} 288$ in dIIb of calpain, forces the subdomain $\mathrm{B}$ to occupy and bind to the cleft; 3 ) the rearrangement of the domains relative to one another allows the simultaneous interaction of calpastatin with both $\mathrm{dIII}$ and the protease core, which increases the area of interaction, and thus the overall affinity of calpastatin for calpain.

\section{Acknowledgements}

Supported by the Research Program of The Education Department of Gansu Province, China (No. 0502-01).

\section{REFERENCES}

Bendtsen JD, Nielsen H, Heijne G, Brunak S (2004) Improved prediction of signal peptides: SignalP 3.0. J Mol Biol 340: 783-795.

Betts R, Weinsheimer S, Blouse GE, Anagli J (2003) Structural determinants of the calpain inhibitory activity of calpastatin peptide B27W'T. J Biol Chem 278: 7800-7809.

Carragher NO, Westhoff MA, Riley D, Potter DA, Dutt P, Elce JS, Greer PA, Frame MC (2002) v-Src-induced modulation of the calpain-calpastatin proteolytic system regulates transformation. Mol Cell Biol 22: 257-269.

Chou PY (1990) Prediction of protein structural classes from amino acid composition. In Prediction of protein structure and the principles of protein conformation. Plenum Press, New York, NY.

Chou PY, Fasman GD (1978) Prediction of the secondary structure of proteins from their amino acid sequence. Adv Ensymol 47: 45-148.

Croall DE, Demartino GN (1991) Calcium-activated neutral protease (calpain) system: structure, function, and regulation. Physiol Rev 71: 813-847.

Emori Y, Kawasaki H, Imajoh S, Minami Y, Suzuki K (1988) All four repeating domains of the endogenous inhibitor for calcium-dependent protease independently retain inhibitory activity. J Biol Chem 263: 2364-2370.

Glading A, Lauffenburger DA, Wells A (2002) Cutting to the chase: calpain proteases in cell motility. Trends Cell Biol 12: 46-54.

Goll DE, Thompson VF, Li H, Wei W, Cong J (2003) The calpain system. Physiol Rev 83: 731-801.

Hall TA (1999) BioEdit: a user-friendly biological sequence alignment editor and analysis program for Windows 95/98/NT. Nucl Acids Symp Ser 41: 95-98.

Hanna RA, Robert LC, Peter LD (2008) Calcium-bound structure of calpain and its mechanism of inhibition by calpastatin. Nature 456: 409-412.

Hanna RA, Garcia-Diaz BE, Davies PL (2007) Calpastatin simultaneously binds four calpains with different kinetic constants. FEBS Lett 581: $2894-2898$.

Hao LY, Kameyama A, Kuroki S, Takano J, Takano E, Maki M, Kameyama M (2000) Calpastatin domain $\mathrm{L}$ is involved in the regulation of L-type $\mathrm{Ca}^{2+}$ channels in guinea pig cardiac myocytes. Biochem Biophys Res Commun 279: 756-761.

Hirose K, Kadowaki S, Tanabe M, Takeshima H, Iino M (1999) Spatiotemporal dynamics of inositol 1,4,5-trisphosphate that underlies complex $\mathrm{Ca}^{2+}$ mobilization patterns. Science 284: 1527-1530.

Kawasaki H, Emori Y, Imajoh-ohmi S, Minami Y, Suzuki K (1989) Identification and characterization of inhibitory sequences in four repeating domains of the endogenous inhibitor for calcium dependent protease. J Biochem 106: 274-281.
Kiss R, Bozoky Z, Kovacs D, Rona G, Friedrich P, Dvortsak P, Weisemann R, Tompa P, Perczel A (2008a) Calpain-induced tripartite binding of intrinsically disordered calpastatin to its cognate enzyme, calpain. FEBS Lett 582: 2149-2154.

Kiss R, Kovacs D, Tompa P, Perczel A (2008b) Local structural preferences of calpastatin, the intrinsically unstructured protein inhibitor of calpain. Biochemistry 47: 6936-6945.

Maki M, Takano E, Mori H, Sato A, Murachi T, Hatanaka M (1987) All four internally repetitive domains of pig calpastatin possess inhibitory activities against calpains I and II. FEBS Lett 223: 174-180.

Maki M, Takano E, Osawa T, Ooi T, Murachi T, Hatanaka M (1988) Analysis of structure-function relationship of pig calpastatin by expression of mutated cDNAs in Escherichia coli. J Biol Chem 263: 10254-10261.

Melloni E, Averna M, Stifanese R, Tullio RD, Defranchi E, Salamino F, Pontremoli S (2006) Association of calpastatin with inactive calpain. J Biol Chem 281: 24945-24954.

Minobe E, Hao LY, Saud ZA, Xu JJ, Kameyama A, Maki M, Jewell KK, Parr T, Bardsley RG, Kameyama M (2006) A region of calpastatin domain $\mathrm{L}$ that reprimes cardiac L-type $\mathrm{Ca}^{2+}$ channels. Biochem Biophys Res Commun 348: 288-294.

Moldoveanu T, Gehring K, Green DR (2008) Concerted multi-pronged attack by calpastatin to occlude the catalytic cleft of heterodimeric calpains. Nature 456: 404-408.

Mucsi Z, Hudecz F, Hollósi M, Tompa P, Friedrich P (2003) Bindinginduced folding transitions in calpastatin subdomains A and C. Protein Sci 12: 2327-2336.

Pfizer J, Assfalg-Machleidt I, Machleidt W, Chaschke N (2008) Inhibition of human mu-calpain by conformationally constrained calpastatin peptides. Biol Chem 389: 83-90.

Sambrook J, Russell D (2001) Molecular Cloning: A Laboratory Manual. Cold Spring Harbor Laboratory, Press, Cold Spring Harbor, NY.

Shiraha H, Glading A, Chou J, Jia Z, Wells A (2002) Activation of mcalpain (calpain II) by epidermal growth factor is limited by protein kinase A phosphorylation of m-calpain. Mol Cell Biol 22: 2716-2727.

Takano J, Watanabe M, Hitomi K, Maki M (2000) Four types of calpastatin isoforms with distinct amino-terminal sequences are specified by alternative first exons and differentially expressed in mouse tissues. I Biochem (Tokyo) 128: 83-92.

Todd B, Moore D, Deivanayagam CC, Lin GD, Chattopadhyay D, Maki M, Wang KK, Narayana SV (2003) A structural model for the inhibition of calpain by calpastatin: crystal structures of the native domain VI of calpain and its complexes with calpastatin peptide and a small molecule inhibitor. J Mol Biol 328: 131-146.

Toke O, Banoczi Z, Tarkanyi G, Friedrich P, Hudecz F (2009) Folding transitions in calpain activator peptides studied by solution NMR spectroscopy. J Pept Sci 15: 404-410.

Tompa P, Mucsi Z, Orosz G, Friedrich P (2002) Calpastatin subdomains A and C are activators of calpain. J Biol Chem 277: $9022-$ 9026.

Tullio RD, Averna M, Salamino F, Pontremoli S, Melloni E (2000) Differential degradation of calpastatin by $\mu$ - and $\mathrm{m}$-calpain in $\mathrm{Ca}^{2+}$ enriched human neuroblastoma LAN-5 cells. FEBS Lett 475: 17-21.

Uemori T, Shimojo T, Asada K, Asano T, Kimizuka F, Kato I, Maki M, Hatanaka M, Murachi T, Hanzawa H, Arata Y (1990) Characterization of a functional domain of human calpastatin. Biochem Biophys Res Commun 166: 1485-1493.

Weber H, Jonas L, Hühns S, Schuff-Werner P (2004) Dysregulation of the calpain-calpastatin system plays a role in the development of cerulein-induced acute pancreatitis in the rat. Am J Physiol Gastrointest Liver Physiol 286: G932-G941.

Wendt A, Thompson VF, Goll DE (2004) Interaction of calpastatin with calpain: a review. Biol Chem 385: 465-472. 